\title{
The Current State and the Prospects of Innovative Development of Export-Organized Ukrainian Industrial Enterprises
}

\author{
Tetiana Protsiuk ${ }^{1}, 0$ oksana Henyk ${ }^{2}$, Yaroslava Moskvyak ${ }^{3}, 0$ oksana Protsevyat ${ }^{4}$ \\ ${ }^{1}$ Academy of Financial Monitoring \\ 24 Biloruska Street, Kyiv, 04050, Ukraine \\ ${ }^{2}$ National Forestry University of Ukraine \\ 103 General Chuprynka Street, 79057, Lviv, Ukraine \\ ${ }^{3}$ Lviv Polytechnic National University \\ 12 Stepana Bandery Street, Lviv, 79013, Ukraine \\ ${ }^{4}$ Institute of Regional Research named after V. I. Dolishniy of the NAS of Ukraine \\ 4 Kozelnytska Street, Lviv, 79026, Ukraine
}

DOI: $10.22178 /$ pos.38-3

JEL Classification: L53, 032

Received 01.08.2018

Accepted 15.09.2018

Published online 20.09.2018

Corresponding Author:

Tetiana Protsiuk

agat-lviv@ukr.net

(C) 2018 The Authors. This article

is licensed under a Creative Commons

Attribution 4.0 License @ (1)

\begin{abstract}
The purpose of the article is to study the current state and the prospects of innovative development of export-oriented industrial enterprises of Lviv region and of Ukraine on the basis of modern theory and practice in the field of economics and enterprise management. It is established that the innovative activity of Ukrainian industrial enterprises is at a rather low level with the prospect of further reduction. The key obstacles and difficulties arising on the way of innovative development of Ukrainian export-oriented industrial enterprises are highlighted. The ways of solving the problems of innovative development of export-oriented industrial enterprises in Ukraine are offered. The prospect of further research in this area is the study of key aspects of the development of export-oriented industrial enterprises with the prospect of development and increases their export potential.
\end{abstract}

Keywords: innovation; development; industry; enterprise; export; exports potential; Lviv oblast; Ukraine.

\section{INTRODUCTION}

The modern development of the Ukrainian economy may not be imagined without innovation, because these innovations touch the different spheres of economic activity at different levels of functioning. Being particularly noticeable, such phenomena may be observed in the industry, because the innovative development of this type of economic activity is the key to the success of the functioning of industrial enterprises.

The following Ukrainian scholars-economists, such as 0. Amosha [1], L. Kalinichenko [6], L. Salomatina [1], P. Khariv [7], 0 . Khmelevskyy [8], and others have carried out the fundamental research in the field of innovative development of export-oriented industries at micro, meso- and macro levels. The outline of the research issue is also presented in the writings of other (foreign) scholars, in particular A. Eggert [3], R. Varadarajan [15], J. Johanson [5] and other.

At the same time, paying tribute to the high level of modern scientific achievements, we note that the issues (separate problem aspects) regarding the current state and perspectives of innovative development of export-oriented industrial enterprises in Ukraine are not fully studied. This is especially true for export-oriented industrial enterprises of the Lviv region.

The purpose of the article is to study the current state and prospects of innovation development of export-oriented industrial enterprises of Lviv region and Ukraine on the basis of modern theory and practice in the field of economics and enterprise management. 


\section{RESULTS AND DISCUSSION}

It is known that today in the world, including Ukraine, there is a significant demand for hightech products. At the same time, the research confirms the significant dependence of export of products on its innovative characteristics. Therefore, in order to increase the level of export of Ukrainian products abroad, first of all, it is necessary to pay attention to its innovative characteristics, and how much it can meet the needs of foreign markets.

It is revealed that the key characteristic features of export-oriented industrial enterprises are their export and innovation-investment capacity. Moreover, export capacity depends on the level of competitiveness, production, financial and export potential of the enterprise [8].

Today, the path of Ukrainian enterprises to export of products is endowed with numerous obstacles and difficulties, the main place among which occupy the following features [4]:

- the difficulties of ignorance of foreign markets;

- the problems of adaptation to new markets;

- the unknown information about Ukrainian products abroad;

- the low level of activity of Ukrainian producers;

- non-compliance with standards and certification.

In order to minimize the risks of economic and social instability that arose in our country today, as well as to create the conditions and promote the stability of export growth of Ukrainian products (including industrial ones), the Export Strategy of Ukraine was developed: the road map of strategic trade development 2017-2021 [10]. In the context of the implementation of this strategy, it is envisaged to achieve the following main strategic objectives as [10]:

1) to create the favorable conditions for the stimulation of trade processes and the development and the implementation of innovation in the context of export diversification;

2) to ensure the development of services in support of business and trade, which will ultimately increase the competitiveness of participants in foreign economic relations (including small and medium enterprises);

3) to promote the skills and competences of participants in foreign economic relations.

In addition to the above, in order to overcome the problems of innovative development of export-oriented industrial enterprises and to pro- vide the favorable conditions for an innovative environment in which they will operate in the future, it is proposed to undertake a number of further actions [1]:

1) to promote the innovative development both in Ukraine as a whole and in its regions directly in accordance with the developed programs, in particular the program "Horizon 2020" [2];

2) to provide the regional management of the innovation development as a result of interaction with market institutions, which will allow not only to establish further changes that will take place in the market, but also significantly increase the level of competitiveness of these regions, including the economic entities operating there;

3) the geographic diversification of exports of products with high added value through the development and the implementation of new technological chains, referring to the needs of the EU market;

4) to promote the integration not only in European, but also in the world economic space through the development of transnational business;

5) to increase the level of financing of innovation activity.

However, the improvement of the processes of the innovation development of industrial enterprises, in particular export-oriented, requires the introduction of a specially developed system of incentives, which would give a high level of efficiency of the results from the operation of such enterprises. Therefore, in order to solve such a problem, it is necessary, first of all, to improve the existing system of financing by the state on the innovative development of enterprises, including industrial [7].

On the basis by [6], it is established that the state regulation and stimulation in the innovation sphere should do the following:

- promote the development of science and its institutions;

- ensure the development of human capital;

- ensure the participation in the joint innovation programs;

- implement the state orders for joint research and development;

- make the financial incentives for innovation;

- promote attraction of the foreign investments.

Researches show that in the structure of the activities of industrial enterprises, innovation activ- 
ity occupies a prominent place. Thus, the number of industrial enterprises in Ukraine engaged in innovation activity is about one fifth of the total number of the industrial enterprises. In Lviv oblast, a similar situation is observed, but unlike the overall Ukrainian dynamics, the share of industrial enterprises engaged in innovation activities tended to increase (except for a slight reduction in 2014 by $0.2 \%$ ) - from $13.2 \%$ in 2011 to $20.6 \%$ in 2016 [14].

With regard to the absolute values of dynamics, during 2011-2016, both in Ukraine and in the Lviv region, the number of industrial enterprises engaged in innovation activity decreased by almost 2.0 and 1.6 times in 2016, comparing to the beginning of the analyzed period [14].
The largest number of industrial enterprises in the Lviv region in the structure of innovative activities was involved in the purchase of machinery, equipment and software, but with the beginning of the analyzed period, it has decreased by 12 units to the number of 57 industrial enterprises in 2016 [14].

The analysis of statistical data for 2011-2016 confirms the situation of a non-profit, but a sharp decline in the number of the industrial enterprises that implemented the innovations both in Ukraine (by 1.8 times) and in the Lviv region (by 1.3 times) in 2016, comparing to the beginning of the analyzed period (Table 1).

Table 1 - The dynamics and the structure of the number of industrial enterprises that implemented the innovations

\begin{tabular}{|c|c|c|c|c|c|c|c|c|c|c|c|c|}
\hline & \multicolumn{2}{|c|}{2011} & \multicolumn{2}{|c|}{2012} & \multicolumn{2}{|c|}{2013} & \multicolumn{2}{|c|}{2014} & \multicolumn{2}{|c|}{2015} & \multicolumn{2}{|c|}{2016} \\
\hline & unit & $\%$ & unit & $\%$ & unit & $\%$ & unit & $\%$ & unit & $\%$ & unit & $\%$ \\
\hline \multicolumn{13}{|c|}{ Ukraine } \\
\hline Totally & 1327 & 100,0 & 1371 & 100,0 & 1312 & 100,0 & 1208 & 100,0 & 723 & 100,0 & 735 & 100,0 \\
\hline $\begin{array}{l}\text { Those that implemented the } \\
\text { innovative processes }\end{array}$ & 677 & 51,0 & 703 & 51,3 & 665 & 50,7 & 459 & 38,0 & 400 & 55,3 & 526 & 71,6 \\
\hline $\begin{array}{l}\text { Those that are low-waste, } \\
\text { resource-saving }\end{array}$ & 605 & 89,4 & 598 & 85,1 & 557 & 83,8 & 141 & 30,7 & 155 & 38,8 & 235 & 44,7 \\
\hline $\begin{array}{l}\text { Those that introduced the } \\
\text { innovative species }\end{array}$ & 731 & 55,1 & 704 & 51,3 & 683 & 52,1 & 600 & 49,7 & 414 & 57,3 & 529 & 72,0 \\
\hline Those that are new at the market & 184 & 25,2 & 166 & 23,6 & 171 & 25,0 & 137 & 22,8 & 114 & 27,5 & 166 & 31,4 \\
\hline \multicolumn{13}{|c|}{ Lviv oblast } \\
\hline Totally & 74 & 100,0 & 81 & 100,0 & 84 & 100,0 & 99 & 100,0 & 61 & 100,0 & 58 & 100,0 \\
\hline $\begin{array}{l}\text { Those that implemented the } \\
\text { innovative processes }\end{array}$ & 38 & 51,4 & 49 & 60,5 & 42 & 50,0 & 37 & 37,4 & 44 & 72,1 & 46 & 79,3 \\
\hline $\begin{array}{l}\text { Those that are low-waste, } \\
\text { resource-saving }\end{array}$ & 33 & 86,8 & 42 & 85,7 & 37 & 88,1 & 8 & 21,6 & 11 & 25,0 & 22 & 47,8 \\
\hline $\begin{array}{l}\text { Those that introduced the } \\
\text { innovative species }\end{array}$ & 37 & 50,0 & 43 & 53,1 & 47 & 56,0 & 42 & 42,4 & 27 & 44,3 & 45 & 77,6 \\
\hline Those that are new at the market & 12 & 32,4 & 8 & 18,6 & 17 & 36,2 & 10 & 23,8 & 10 & 37,0 & 17 & 37,8 \\
\hline
\end{tabular}

The source: based on Statistical Information State Statistics Service of Ukraine and Main Department of Statistics in Lviv Oblast $[9,14]$

In particular, a significant decrease in the number occurred among the industrial enterprises that implemented the low-resource and the resource-saving innovations. Thus, according to allUkrainian standards, the number of such enterprises has decreased by 2.6 times, and in the Lviv region - only by 1.5 times.

The explanation of the situation of reducing the level of innovation activity of industrial enterprises, including industry, as a type of economic activity in general, is the emergence of diverse obstacles. In particular, the defining position in the list of obstacles is:

1) the economic and political instability in the state;

2) the migration of highly educated and skilled scientists and youth;

3) the insufficient development of the innovation infrastructure in the state;

4) the low level of financing of innovations; 
5) the insignificant support of the investment funds, caused by the low level of development of the regulatory system and the taxation of their activities.

In the structure of innovation costs of industrial enterprises both in Lviv oblast and in Ukraine in general, during 2011-2016, the cost of purchasing machines, equipment and software was prevalent. However, in 2016, unlike the national values, where their share in the structure of innovation costs increased by $12.2 \%$, the share of innovative costs for the purchase of machinery, equipment and software in the Lviv region decreased by $14.9 \%$ comparing to the beginning of the analyzed period (Table 2).

Table 2 - The dynamics and the structure of expenses of industrial enterprises in directions of their innovation activity

\begin{tabular}{|c|c|c|c|c|c|c|c|c|c|c|c|c|}
\hline & \multicolumn{2}{|l|}{2011} & \multicolumn{2}{|l|}{2012} & \multicolumn{2}{|l|}{2013} & \multicolumn{2}{|l|}{2014} & \multicolumn{2}{|l|}{2015} & \multicolumn{2}{|l|}{2016} \\
\hline & th. hrn & $\%$ & th. hrn & $\%$ & th. hrn & $\%$ & th. hrn & $\%$ & th. hrn & $\%$ & th. hrn & $\%$ \\
\hline \multicolumn{13}{|c|}{ Ukraine } \\
\hline \begin{tabular}{|l|} 
Total \\
expenses
\end{tabular} & 14333891,9 & 100,0 & 11480562,8 & 100,0 & 9562626,0 & 100,0 & 7695892,3 & 100,0 & 13813674,4 & 100,0 & 23229458,1 & 100,0 \\
\hline \multicolumn{13}{|l|}{ In particular: } \\
\hline $\begin{array}{l}\text { The } \\
\text { internal } \\
\text { GDR }\end{array}$ & 833285,7 & 5,8 & 965166,5 & 8,4 & 1312054,4 & 13,7 & 1221435,6 & 15,9 & 1834084,6 & 13,3 & 2063744,9 & 8,9 \\
\hline $\begin{array}{l}\text { The } \\
\text { external } \\
\text { GDR }\end{array}$ & 246631,0 & 1,7 & 231111,6 & 2,0 & 326385,8 & 3,4 & 533104,2 & 6,9 & 205377,3 & 1,5 & 394049,0 & 1,7 \\
\hline $\begin{array}{l}\text { The } \\
\text { purchase of } \\
\text { machinery, } \\
\text { equipment } \\
\text { and } \\
\text { software }\end{array}$ & 10489087,2 & 73,2 & 8051762,9 & 70,1 & 5546329,0 & 58,0 & 5115338,1 & 66,5 & 11141256,4 & 80,7 & 19829026,5 & 85,4 \\
\hline $\begin{array}{l}\text { Other } \\
\text { outside } \\
\text { knowledge }\end{array}$ & 324701,6 & 2,3 & 47043,7 & 0,4 & 86978,8 & 0,9 & 47235,4 & 0,6 & 84909,9 & 0,6 & 64212,4 & 0,3 \\
\hline \begin{tabular}{|l} 
Other \\
expenses
\end{tabular} & 2440186,4 & 17,0 & 2185478,1 & 19,0 & 2290878,0 & 24,0 & 778779,0 & 10,1 & 548046,2 & 4,0 & 878425,3 & 3,8 \\
\hline \multicolumn{13}{|c|}{ Lviv oblast } \\
\hline $\begin{array}{l}\text { Total } \\
\text { expenses }\end{array}$ & 162676,8 & 100,0 & 280614,4 & 100,0 & 257053,9 & 100,0 & 219754,3 & 100,0 & 277796,2 & 100,0 & 429278,9 & 100,0 \\
\hline \multicolumn{13}{|l|}{ In particular: } \\
\hline $\begin{array}{l}\text { The } \\
\text { internal } \\
\text { GDR }\end{array}$ & 7454,7 & 4,6 & 9053,5 & 3,2 & 7735,6 & 3,0 & 13744,6 & 6,3 & 35825,3 & 12,9 & 35875,3 & 8,4 \\
\hline $\begin{array}{l}\text { The } \\
\text { external } \\
\text { GDR } \\
\end{array}$ & 414,6 & 0,3 & 1399,0 & 0,5 & 7983,8 & 3,1 & 3103,2 & 1,4 & 12748,6 & 4,6 & 12667,4 & 3,0 \\
\hline $\begin{array}{l}\text { The } \\
\text { purchase of } \\
\text { machinery, } \\
\text { equipment } \\
\text { and } \\
\text { software }\end{array}$ & 148192,8 & 91,1 & 259954,9 & 92,6 & 232494,4 & 90,4 & 149875,6 & 68,2 & 202756,6 & 73,0 & 327293,6 & 76,2 \\
\hline \begin{tabular}{|l|} 
Other \\
outside \\
knowledge \\
\end{tabular} & 221,8 & 0,1 & 268,1 & 0,1 & 578,7 & 0,2 & 219,2 & 0,1 & 1464,9 & 0,5 & 559,5 & 0,1 \\
\hline $\begin{array}{l}\text { Other } \\
\text { expenses }\end{array}$ & 6392,9 & 3,9 & 9938,9 & 3,5 & 8261,4 & 3,2 & 52811,7 & 24,0 & 25000,8 & 9,0 & 52883,1 & 12,3 \\
\hline
\end{tabular}

The source: based on Statistical Information State Statistics Service of Ukraine and Main Department of Statistics in Lviv Oblast $[9,14]$ 
Regarding the financing of innovative activity of the industrial enterprises, the largest share in the structure of the volume of financing of innovation activity of the industrial enterprises takes funds from their own sources. However, in 2016, the share of these sources of financing for innovative activity of industrial enterprises of Lviv Oblast decreased by $8.6 \%$ comparing to 2011 , as opposed to the Ukrainian indicator, where a significant increase in the share of such sources of funding was observed for $41.9 \%$ (Table 3). The second place in the structure of sources of financing is taken by loans, which are gaining in popularity among the industrial enterprises of the Lviv region, the increase in their share by $16.0 \%$ in 2016 is the evident, comparing to the beginning of the analyzed period. Ukraine has the opposite trend where there is a sharp decline in the share of these sources of financing innovative activity (by $35.6 \%$ in 2016, comparing to 2011).

Table 3 - The dynamics and the structure of innovation activity financing of industrial enterprises

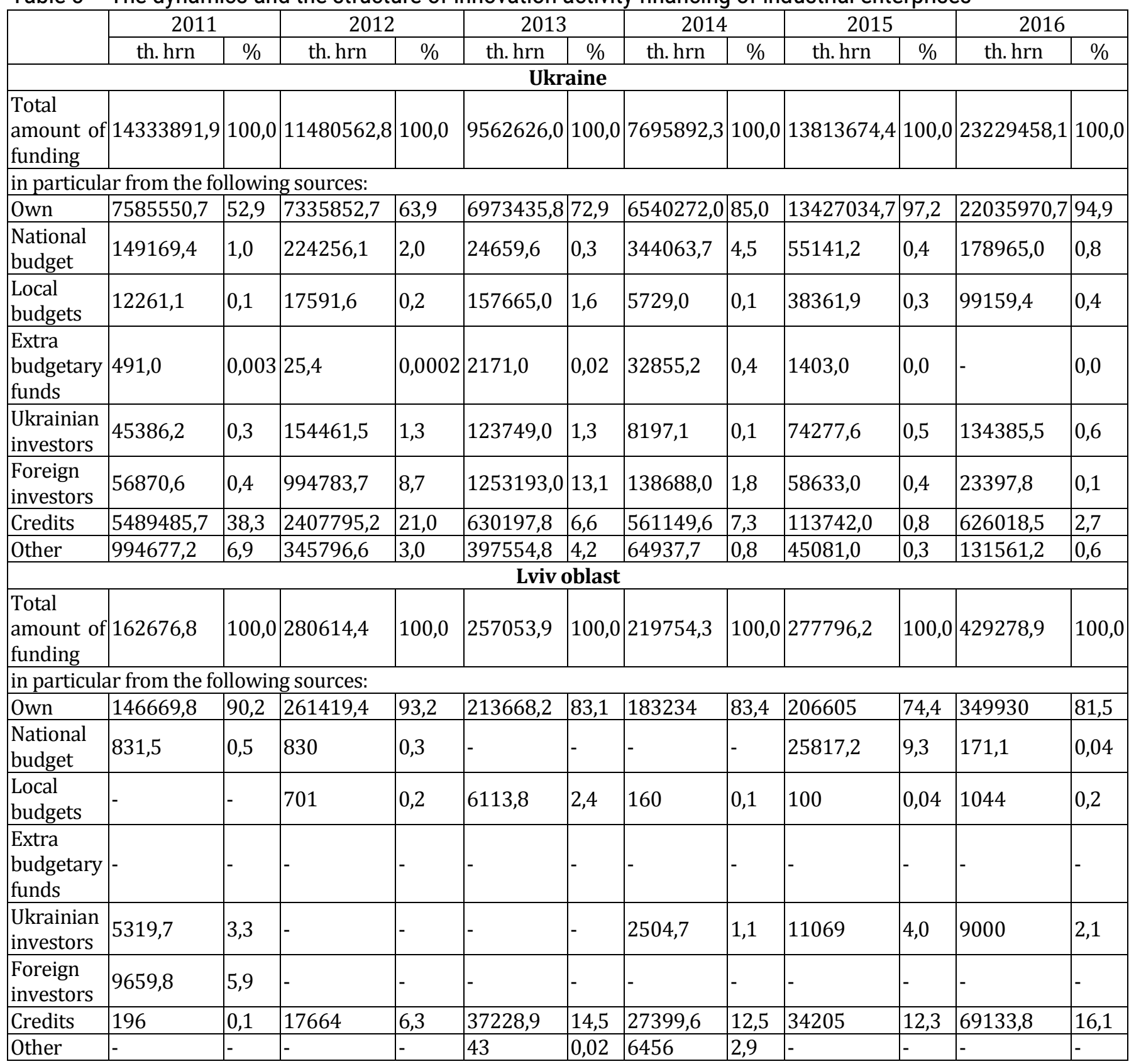

The source: based on Statistical Information State Statistics Service of Ukraine and Main Department of Statistics in Lviv Oblast $[9,14]$

Researches show that in Ukraine, in particular in the Lviv region, there is a fairly low share of the volume of sales of innovative products in the structure of the total volume of the industrial 
products sold (does not exceed $3.2 \%$ for the entire analyzed period) (Table 4). As for the implementation of innovative products abroad, in Ukraine, the share of the volume of sales of innovative products in the volume of the realized in- novation products increased significantly - in 2016 by $17.2 \%$, as comparing to 2011 . Instead, in the Lviv region, the opposite trend is observed - there was a fall in the share by $7.7 \%$.

Table 4 - The dynamics and the structure of volumes of the realized innovative products

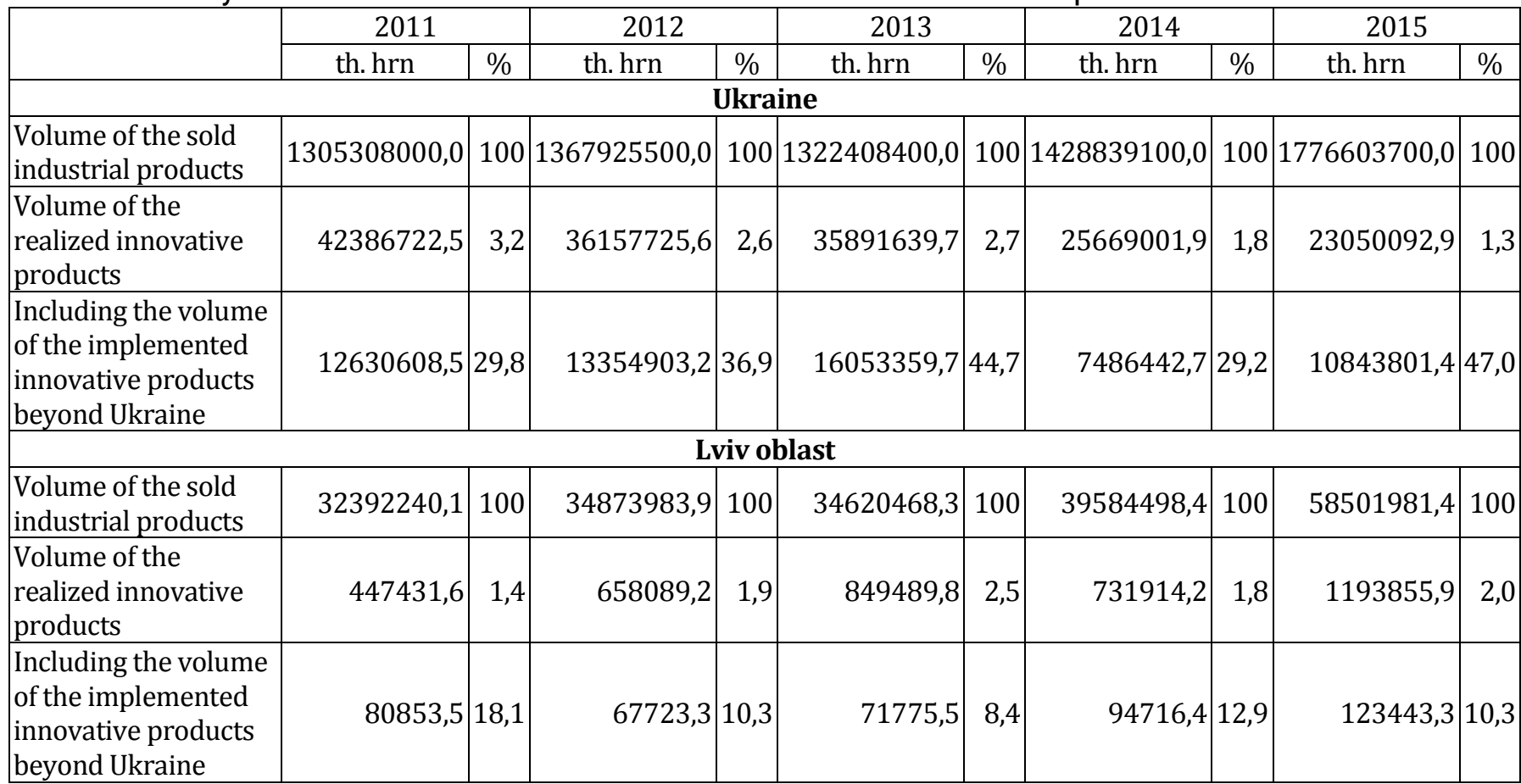

The source: based on Statistical Information State Statistics Service of Ukraine and Main Department of Statistics in Lviv Oblast $[9,14]$

According to the researches carried out by [1] one of the key reasons of the low level of sales of innovative products is the low demand for these products both in the domestic and in the external market.

It is clear from the mentioned above that such a situation not only acts as a factor in reducing the competitiveness of the innovative products, but it is also a major problem in the development of the export potential of the industrial enterprises engaged in the innovation activities and innovations.

\section{CONCLUSIONS}

Consequently, on the basis of the research of the theory and practice of the current state of innovation development of the export-oriented industrial enterprises of Lviv region and Ukraine as a whole, it was established that the innovative activity of Ukrainian industrial enterprises is at a rather low level with the prospect of the further reduction.

The prospect of the further research in this area is the research of key aspects of the development of the export-oriented industrial enterprises with the prospect of the development and the increase of their export potential.

\section{REFERENCES}

1. Amosha, O., Salomatina, L. (2017). Innovative development of industrial enterprises in the regions: problems and prospects. Economy of Ukraine, 3, 20-34 (in Ukrainian).

2. Cabinet of Ministers of Ukraine. (2017). Horizon 2020. Retrieved from https://www.kmu.gov.ua/storage/app/media/uploaded-files/broshura-gorizont-20201201.pdf (in Ukrainian). 
3. Eggert, A., Thiesbrummel, C., \& Deutscher, C. (2015). Heading for new shores: Do service and hybrid innovations outperform product innovations in industrial companies? Industrial Marketing Management, 45, 173-183. doi: 10.1016/j.indmarman.2015.02.013

4. Hryntsevych, S. (2017, May 20). Export of industrial high-tech. Retrieved from https://appau.org.ua/info/eksport-promyslovyh-haj-tek-kejs-appau/ (in Ukrainian).

5. Johanson, J., \& Mattsson, L.-G. (2015). Internationalisation in Industrial Systems - A Network Approach. Knowledge, Networks and Power, 111-132. doi: 10.1057/9781137508829_5

6. Kalinichenko, L. (2016). Innovative development model of Ukraine in the conditions of European integration processes. Naukovyy visnyk Uzhhorodskoho natsionalnoho universytetu. Seriya: Mizhnarodni ekonomichni vidnosyny ta svitove hospodarstvo, 6(1), 139-143 (in Ukrainian).

7. Khariv, P., \& Mykytyu, P. (2014). Analysis of innovative development of industrial enterprises and ways of its stimulation. Ekonomichnyy analiz, 16(2), 187-195 (in Ukrainian).

8. Khmelevskyy, O. (2015). Export orientation enterprise: essence and features of formation. Visnyk Khmelnytskoho natsionalnoho universytetu. Ekonomichni nauky, 2(4), 47-53 (in Ukrainian).

9. Main Statistical Office in Lviv Region. (2018). Statistical Information. Retrieved August 1, 2018, from http://www.lv.ukrstat.gov.ua/ukr/si/inf_2009.php?ind_page=si (in Ukrainian).

10. Ministry of Economic Development and Trade of Ukraine. (2017). Export strategy of Ukraine: road map of strategic trade development 2017-2021. Retrieved from http://me.gov.ua/Files/GetFile?lang=uk-UA\&fileId=8169f781-0815-4da6-9124-cea43aa699d2 (in Ukraine)

11. National Academy of Sciences of Ukraine. (2015). Innovative Ukraine 2020: national report. Kyiv: $\mathrm{n}$. d. (in Ukraine).

12. Skrynkovskyy, R. (2015). Diagnostics of the foreign economic activity of the enterprise: methodical and criterial support [Diahnostyka zovnishnoekonomichnoi diialnosti pidpryiemstva: metodychne ta kryterialne zabezpechennia]. Everything in the name of science!, 2, 62-66 (in Ukrainian).

13. Skrynkovskyy, R., Pawlowski, G., Kostiuk, N., \& Koropetskyi, O. (2017). Diagnostics of Factors of Enterprise Innovation Development. The Problems of Economy, 1, 250-257 (in Ukrainian).

14. State Statistics Service of Ukraine. (2018). Statistical Information. Retrieved August 1, 2018, from http://www.ukrstat.gov.ua/operativ/menu/menu_u/tda.htm (in Ukrainian).

15. Varadarajan, R. (2015). Innovating for sustainability: a framework for sustainable innovations and a model of sustainable innovations orientation. Journal of the Academy of Marketing Science, 45(1), 14-36. doi: 10.1007/s11747-015-0461-6 